\title{
Leveling Up: Women Academic Librarians' Career Progression in Management Positions
}

\author{
Lorelei B. Rutledge
}

\begin{abstract}
This study explored how women academic librarians in management described their career progression compared to those who are not in management positions. Women librarians working full-time in academic libraries were surveyed about their career experiences to explore what barriers they faced in pursuing or persisting in management positions, as well as their perceptions of the factors necessary for success in such positions. After collecting 224 online surveys, 37 semistructured interviews were conducted with a purposive sample of these librarians to provide context for their survey answers. Understanding women academic librarians' perceptions of their careers, especially with regard to barriers that may discourage them from advancing to management positions as well as factors that may help them succeed, can provide insight into how to better support women in management in academic libraries.
\end{abstract}

\section{Introduction}

Although 83 percent of librarians are women, only 58 percent of management positions in ARL (Association of Research Libraries) libraries are held by women. ${ }^{1}$ Although trends have shown women taking on a greater number of management positions in libraries over time, they are still proportionally underrepresented. ${ }^{2}$ This continued inequality raises questions about whether women managers still face real and perceived barriers in career advancement and taking on management opportunities in librarianship. In addition, little research has been done exploring how women have described their experiences in pursuing and holding management positions. ${ }^{3}$ By learning more about how women librarians explain their career progressions and how their experiences differ, we can learn more about the challenges women librarians may face when pursuing or holding management positions and the factors that they feel make them successful. This information can provide insight into how to better support women in management in academic libraries.

Although scholars have offered a variety of reasons why women advance more slowly to management positions in many fields, few of these studies have specifically focused on why women in librarianship or other female-dominated fields are not proportionally represented in management. Little research has examined the perceived barriers that female academic librarians face in pursuing and holding management positions and how those barriers affect their career progressions. Exploring women academic librarians' career trajectories can un-

\footnotetext{
${ }^{*}$ Lorelei B. Rutledge is Associate Librarian in the J. Willard Marriott Library at the University of Utah; email: Lorelei.Rutledge@utah.edu. (2020 Lorelei B. Rutledge, Attribution-NonCommercial (https://creativecommons. org/licenses/by-nc/4.0/) CC BY-NC.
} 
cover more about the factors that encourage women to consider management positions or discourage them from doing so, and how the career paths of women managers differ from those of women nonmanagers. By understanding challenges that women academic library managers face, libraries can better support them and perhaps provide insight into women managers' experiences in female-dominated professions. Understanding barriers that women academic librarians interested in management face, as well as reasons why they might not pursue management, can also provide insight into how to better support women considering management positions in academic libraries.

In response to these deficiencies in current literature about women in academic libraries, this study explored the following research questions:

1. Do women academic librarians feel that they face barriers in pursuing and achieving management positions?

2. What barriers do women academic librarians perceive they face in pursuing and achieving management positions?

3. What factors do women academic librarians who consider themselves successful managers consider important to their success?

4. How do women academic librarians who are in management positions differ from women academic librarians who are not managers in their understanding of selfperceived barriers and factors for success required to achieve management positions?

The purpose of this explanatory sequential mixed-methods study was to explore whether women academic library managers felt that they faced barriers in achieving management positions or managing successfully and how those perceptions differed between women academic librarians who were managers and women academic librarians who were not.

\section{Background}

Scholars across many disciplines have offered reasons for the gap in women's leadership in multiple industries, using metaphors such as the glass ceiling or the labyrinth to describe the systemic barriers that prevent women from rising to leadership positions. ${ }^{4}$ Others have promoted the idea of organizations as gendered in and of themselves, suggesting that job descriptions, organizational hierarchies and other elements of the workplace are structured to favor men. ${ }^{5}$ Other scholars have suggested factors such as a low interest in managing, lack of masculine leadership qualities, and hiring discrimination. ${ }^{6}$ Additional reasons for the gap in women's leadership in industry include organizational hierarchies and procedures that favor men, general bias and discrimination, a lack of flexibility to support having a family life, and a lack of support networks that can help women to advance. ${ }^{7}$ Another primary argument is that women have not yet achieved parity in holding leadership positions because their low self-assessments of their skills and leadership capabilities hold them back from applying for management positions. ${ }^{8}$ This point of view is bolstered by evidence showing that women tend to underestimate their cognitive abilities ${ }^{9}$ and do not negotiate for higher salaries due to lower assessments of their worth when compared to men. ${ }^{10}$

Other research suggests that men get more opportunities to take on management positions in female-dominated fields despite being a numerical minority, a tendency known as the glass escalator phenomenon; instead of facing disadvantages in female-dominated professions because of their sex or gender, many men progress more quickly to higher-status positions, although these effects may be moderated by differences in race, sexuality, and class. ${ }^{11}$ Although women 
have made significant inroads into managerial positions in libraries, many still face challenges in being hired for assigned leadership positions. Several recent qualitative studies sought to learn more about the lived experiences of female library leaders, describing women's perceptions of their leadership and how they came to be leaders. ${ }^{12}$ However, interest in women's leadership in libraries has declined as some argue that women have essentially achieved parity in librarianship, despite clear proportional underrepresentation of women in library leadership positions. ${ }^{13}$

One of the primary arguments advanced in leadership literature suggests that women have not yet achieved parity in holding leadership positions in large measure because they let low assessments of their skills or leadership ability hold them back from applying for formal leadership positions. Schein showed that people tend to associate leadership characteristics with masculinity ${ }_{1}^{14}$ although the strength of this association is weakening over time. ${ }^{15}$ Several studies have shown that both men and women tend to prefer male managers. ${ }^{16}$ Stereotypes that link leadership with masculinity may play a large role in challenges women face in upper management, leading people to perceive women with feminine characteristics as weak leaders and women with perceived masculine characteristics to be judged negatively for transgressing gender roles. ${ }^{17}$ Women in management may also face backlash for showing leadership behavior because they are perceived as less communal and less likable when they do. ${ }^{18}$

Bosak and Sczesny showed that these negative stereotypes can also become internalized, causing women to doubt that they are good leadership material. ${ }^{19}$ Hogue and Lord suggested that women may also internalize gender stereotypes and develop implicit rules that encourage them to take on follower rather than leadership roles. ${ }^{20}$ Ely and Rhode highlighted research suggesting that women may struggle to integrate a sense of themselves as leaders into their self-identity. ${ }^{21}$ Women who are exposed to images of men and women in stereotypically gendered roles tend to have stronger implicit gender stereotypes, assuming that men would make better leaders after being primed with these images. Women in the same study who were exposed to men and women in nonstereotypical roles (such as those in which women are leaders) still tended to rate their perceptions of themselves as leaders lower instead of being primed to think of themselves as more like leaders after seeing the images, demonstrating the strength of internalized stereotypes. ${ }^{22}$ These studies demonstrated that internalized stereotypes, such as those that link management with masculinity, may influence women's perceptions of their leadership skills.

\section{Methods}

This IRB-exempted study used an explanatory sequential mixed methods design, which began with a quantitative phase to investigate relationships between variables and then moved to a qualitative phase to gather more information about the phenomenon being studied. ${ }^{23}$ An online survey collected basic demographic information about respondents, their perceptions of barriers faced in pursuing management positions, and their perceptions of factors that promoted success in getting and holding management positions. Both women academic librarians who were already in management positions and those who were not were invited to participate to examine whether women academic librarians who are in management positions perceive different barriers to pursuing management than women academic librarians who were not in those positions. Only participants who worked full-time in libraries and were in library positions at the time of the survey were included. After pilot testing the instrument for face validity, the survey was distributed via professional networks such as American Library Association listservs. 
The qualitative portion of this research included semistructured interviews with a purposive, nonprobabilistic sample drawn from the survey respondents. Women in management positions, women aspiring to manage, women who had been managers in the past, and women who had never managed and did not want to were questioned about their management experiences, aspirations for management or lack thereof, and barriers to management or factors that made them successful. Theoretical coding of the interview transcripts and notes was done to derive themes from the interviews to answer the research questions.

\section{Survey Results}

A total of 304 participants responded to the survey, but only 224 of the surveys were complete and met inclusion criteria, which stipulated that the participant be a woman academic librarian working full-time in a library position. Most respondents (93\%) identified themselves as White or Caucasian. About 71 percent of respondents were from institutions where librarians are faculty. More than half (53\%) were tenured, another 20 percent were on a tenure track, and about 20 percent were nonfaculty but on a continuing appointment. Most respondents (63\%) were at doctorate-granting institutions. Roughly one-third $(32 \%)$ identified as primary caregivers for children, elderly parents, or other relatives.

The survey also gathered data about how long participants had worked in academic librarianship, their current institutions, and their current positions. Nearly half $(47 \%)$ of respondents had worked in academic librarianship for 10 years or less, while 16 percent had worked in academic libraries for 26 years or more (see table 1 ).

More than 50 percent had been in their cur-

\begin{tabular}{|c|c|c|}
\hline \multicolumn{3}{|c|}{$\begin{array}{c}\text { TABLE 1 } \\
\text { The Number of Years Respondents } \\
\text { Worked in Academic Libraries (n= 222) }\end{array}$} \\
\hline Years & $\begin{array}{c}\text { Percentage of } \\
\text { Responses }\end{array}$ & $\begin{array}{c}\text { Number of } \\
\text { Responses }\end{array}$ \\
\hline $0-5$ & $18.92 \%$ & 42 \\
\hline $6-10$ & $27.93 \%$ & 62 \\
\hline $11-15$ & $16.22 \%$ & 36 \\
\hline $16-20$ & $14.86 \%$ & 33 \\
\hline $21-25$ & $6.76 \%$ & 15 \\
\hline $26-30$ & $6.76 \%$ & 15 \\
\hline $31+$ & $8.56 \%$ & 19 \\
\hline
\end{tabular}
rent institution for five years or less, and 78 percent had been in their current position for five years or less (see table 2).

Using branched logic in SurveyMonkey, managers and non-managers were asked sepa-

\section{TABLE 2}

The Number of Years Respondents Were in Their Current Institutions $(\mathbf{n}=\mathbf{2 2 3})$

\begin{tabular}{|c|c|c|}
\hline Years & $\begin{array}{c}\text { Percentage of } \\
\text { Responses }\end{array}$ & $\begin{array}{c}\text { Number of } \\
\text { Responses }\end{array}$ \\
\hline $0-5$ & $55.16 \%$ & 123 \\
\hline $6-10$ & $17.49 \%$ & 39 \\
\hline $11-15$ & $11.21 \%$ & 25 \\
\hline $16-20$ & $7.62 \%$ & 17 \\
\hline $21-25$ & $3.59 \%$ & 8 \\
\hline $26-30$ & $2.24 \%$ & 5 \\
\hline $31+$ & $2.69 \%$ & 6 \\
\hline
\end{tabular}
rately about challenges they faced (Appendix A). One hundred forty of the respondents were current managers and 84 were not managers. Of the managers who answered, about $44 \%$ were at the rank of Department Head or a similar position. $21.43 \%$ listed their rank as other, most of which were various middle management ranks, such as division head or unit head (Table 3).

The bulk of the respondents had been managers for five years or less (see table 4).

Current managers were asked to select challenges that they faced in pursuing or performing in their position (see table 5). Eight participants stated that they faced no chal- 


\begin{tabular}{|l|c|c|}
\hline \multicolumn{3}{|c|}{ TABLE 3} \\
\hline Respondents Who Were Managers by Rank (n= 140) \\
\hline Dean/Director/University Librarian & Percentage of Responses & Number of Responses \\
\hline $\begin{array}{l}\text { Associate Dean/Associate University Librarian/ } \\
\text { Associate Director }\end{array}$ & $15.71 \%$ & 22 \\
\hline Department Head/Department Chair & $18.57 \%$ & 26 \\
\hline Other management rank (please specify) & $44.29 \%$ & 62 \\
\hline
\end{tabular}

lenges in their current position and also listed no other challenges they had faced. Of those who chose the "Other" option, the most commonly mentioned challenges were conflicts with administration based on different management styles and conflict related to rank and faculty status. The major challenges participants listed included needing to learn new skills, balancing work and family, learning to think of themselves as managers, and managing political difficulties.

\begin{tabular}{|c|c|c|}
\hline \multicolumn{3}{|c|}{$\begin{array}{c}\text { TABLE } 4 \\
\text { Number of Years as Managers }(n=140)\end{array}$} \\
\hline Years & $\begin{array}{l}\text { Percentage of } \\
\text { Responses }\end{array}$ & $\begin{array}{l}\text { Number of } \\
\text { Responses }\end{array}$ \\
\hline $0-5$ & $52.14 \%$ & 73 \\
\hline $6-10$ & $14.29 \%$ & 20 \\
\hline $11-15$ & $12.86 \%$ & 18 \\
\hline $16-20$ & $6.43 \%$ & 9 \\
\hline $21+$ & $14.29 \%$ & 20 \\
\hline
\end{tabular}
These themes were also prominent in the interviews conducted during the second phase of the research.

\begin{tabular}{|l|c|c|}
\hline \multicolumn{2}{|c|}{ TABLE 5 } \\
\hline Barrier & $\begin{array}{c}\text { Percentage of } \\
\text { Responses }\end{array}$ & $\begin{array}{l}\text { Number of } \\
\text { Responses }\end{array}$ \\
\hline I had to learn new skills to be a manager & $72.86 \%$ & 102 \\
\hline I had to balance work and family life & $60.00 \%$ & 84 \\
\hline I had to learn to think of myself as a manager & $57.14 \%$ & 80 \\
\hline I faced political difficulties in my organization & $57.14 \%$ & 80 \\
\hline I had to relocate & $37.86 \%$ & 54 \\
\hline I have faced gender or sex discrimination & $27.86 \%$ & 39 \\
\hline I have faced age discrimination & $26.43 \%$ & 37 \\
\hline Other (please specify) & $12.86 \%$ & 18 \\
\hline I have faced discrimination based on my level of ability or disability & $5.71 \%$ & 8 \\
\hline I have faced other forms of discrimination & $2.86 \%$ & 4 \\
\hline I have faced racial discrimination & $2.14 \%$ & 3 \\
\hline I have faced discrimination based on my sexual orientation & $2.14 \%$ & 3 \\
\hline I have not faced any challenges in my current management position & $5.00 \%$ & 8 \\
\hline
\end{tabular}

When asked whether they felt successful in their current positions, 73 percent of current managers said yes, and 27 percent were unsure. No one said they felt that they were not successful. Women who defined themselves as successful were directed using branched logic to choose from a list of possible reasons drawn from the literature describing why they felt suc- 
cessful or to write in reasons that were not listed. Most of them said their skills helped most of all, but others mentioned that their personalities, as well as strong support networks, aided in their success. In the "Other" category, many mentioned support from their supervisors and their ability to self-reflect on their management skills and course correct when needed (see table 6).

\begin{tabular}{|l|c|c|}
\hline \multicolumn{3}{|c|}{ TABLE 6 } \\
\hline Reasons for Success & $\begin{array}{c}\text { Percentage } \\
\text { of Responses }\end{array}$ & $\begin{array}{c}\text { Number of } \\
\text { Responses }\end{array}$ \\
\hline My management skills & $75.59 \%$ & 96 \\
\hline My personality & $73.23 \%$ & 93 \\
\hline Support from my employees & $65.35 \%$ & 83 \\
\hline Support from a network of peers & $59.84 \%$ & 76 \\
\hline My prior experience as a manager & $58.27 \%$ & 74 \\
\hline My confidence in myself as a manager & $51.97 \%$ & 66 \\
\hline Support from a mentor & $50.39 \%$ & 64 \\
\hline My ability to manage stress & $48.03 \%$ & 61 \\
\hline My ability to manage political difficulties & $47.24 \%$ & 60 \\
\hline $\begin{array}{l}\text { Organizationally sponsored management training } \\
\text { (including leadership institutes) }\end{array}$ & $46.46 \%$ & 59 \\
\hline Self-led management training & & \\
\hline Other (please specify) & $42.52 \%$ & 54 \\
\hline
\end{tabular}

Current managers who indicated that they were unsure whether or not they were successful were asked to write a few sentences describing why they felt uncertain about their management skills. These responses were coded for common themes, which are shown in table 7 . The most common reason mentioned for uncertainty about management success was that participants were unsure how to measure their success and did not get explicit feedback about it. Most mentioned that they felt they did well in some areas and not in others. Several mentioned recalcitrant staff who were resistant to their efforts to introduce new technologies or change work processes, leading them to question themselves.

\begin{tabular}{|l|c|c|}
\hline \multicolumn{3}{|c|}{ TABLE 7 } \\
\hline Reasons & $\begin{array}{c}\text { Percentage of } \\
\text { Responses }\end{array}$ & $\begin{array}{c}\text { Number of } \\
\text { Responses }\end{array}$ \\
\hline I am new to the position & $18.92 \%$ & 7 \\
\hline I am not sure of the metrics to measure success & $18.92 \%$ & 7 \\
\hline I am overwhelmed by other responsibilities & $16.22 \%$ & 6 \\
\hline I haven't gotten any feedback & $10.81 \%$ & 4 \\
\hline I doubt myself & $8.10 \%$ & 3 \\
\hline I have gotten negative feedback & $8.10 \%$ & 3 \\
\hline
\end{tabular}


Of the 84 nonmanagers, half indicated an interest in managing in the future, 30 percent were unsure about it, and 20 percent did not want to manage. Of those who were interested in management, 57 percent had applied for a management position in the past, while 43 percent had not. Those interested in management were asked what challenges they faced in getting management positions (see table 8). The number one challenge was political difficulties. Forty-two percent also said they faced other difficulties, which the comments suggested were difficulties getting the supervisory experience to move up, especially in flat organizations with few management opportunities.

\begin{tabular}{|l|c|c|}
\hline \multicolumn{2}{|c|}{ BABLE 8 } \\
\hline \multicolumn{2}{|c|}{ Barriers Women Faced Obtaining Management Positions (n = 41) } \\
\hline Barriers to Obtaining Management Positions & $\begin{array}{l}\text { Percentage } \\
\text { of Responses }\end{array}$ & $\begin{array}{l}\text { Number of } \\
\text { Responses }\end{array}$ \\
\hline I face political difficulties in my organization & $41.46 \%$ & 17 \\
\hline Other (please specify) & $41.46 \%$ & 17 \\
\hline I can't relocate to pursue a management position & $31.71 \%$ & 13 \\
\hline I don't have the skills to be a manager & $17.07 \%$ & 7 \\
\hline $\begin{array}{l}\text { I have faced gender or sex discrimination that has prevented me from } \\
\text { getting a management job }\end{array}$ & $14.63 \%$ & 6 \\
\hline $\begin{array}{l}\text { I have faced age discrimination that has prevented me from getting a } \\
\text { management position }\end{array}$ & $14.63 \%$ & 6 \\
\hline $\begin{array}{l}\text { I don't have time to take the additional responsibilities required by a } \\
\text { management position because I am too busy with my current work }\end{array}$ & $12.20 \%$ & 5 \\
\hline $\begin{array}{l}\text { I don't have time to take on the additional responsibilities required by a } \\
\text { management position because I am too busy being the primary caregiver } \\
\text { for children or other relatives }\end{array}$ & $7.32 \%$ & 3 \\
\hline I don't think of myself as a manager & & \\
\hline $\begin{array}{l}\text { I have faced discrimination based on my level of ability or disability that has } \\
\text { challenged me as a manager }\end{array}$ & $7.32 \%$ & 3 \\
\hline $\begin{array}{l}\text { I have faced other forms of discrimination that have prevented me from } \\
\text { getting a management position }\end{array}$ & $4.88 \%$ & 3 \\
\hline I have not faced any challenges in getting a management position & $4.88 \%$ & 3 \\
\hline $\begin{array}{l}\text { I have faced racial discrimination that has prevented me from getting a } \\
\text { management position }\end{array}$ & $0.00 \%$ & 0 \\
\hline
\end{tabular}

Women who indicated that they were not interested in management were directed via branched logic in SurveyMonkey to choose from a list of possible reasons why they might not want to pursue a management position drawn from the literature. Major reasons they listed included not wanting to have to supervise employees, not wanting to deal with the stress associated with managing and supervision, and being happy in their current position (see table 9). In the "Other" category, reasons participants listed included not wanting to spend more time at work, wanting a no-stress job, wanting the "fun" assignments that usually go to librarians who are not managers, and wanting to stay away from the "boys' club" of upper management. 


\begin{tabular}{|l|c|c|}
\hline \multicolumn{2}{|c|}{ TABLE 9 } \\
\hline Reasons for Disinterest in Management & $\begin{array}{l}\text { Percentage } \\
\text { of Responses }\end{array}$ & $\begin{array}{l}\text { Number of } \\
\text { Responses }\end{array}$ \\
\hline I don't want to supervise people & $76.47 \%$ & 13 \\
\hline I don't want the stress of a management position & $76.47 \%$ & 13 \\
\hline I don't want the political difficulties managers face & $70.59 \%$ & 12 \\
\hline I am happy in my current position & $58.82 \%$ & 10 \\
\hline I have done it in the past and did not like it & $35.29 \%$ & 6 \\
\hline I don't have the skills necessary to be a manager & $29.41 \%$ & 5 \\
\hline Please list other reasons why you do not want to be a manager & $23.53 \%$ & 4 \\
\hline $\begin{array}{l}\text { I don't have time to take on the addition responsibilities required in a } \\
\text { management position because I am too busy being a primary caregiver for } \\
\text { children or other relatives, }\end{array}$ & $11.76 \%$ & 2 \\
\hline I don't think of myself as a manager & & \\
\hline $\begin{array}{l}\text { I prefer to use my influence outside of the library's formal management } \\
\text { structure }\end{array}$ & $11.76 \%$ & 2 \\
\hline $\begin{array}{l}\text { I don't have time to take on the addition responsibilities required in a } \\
\text { management position because I am too busy with my current work. }\end{array}$ & $5.88 \%$ & 1 \\
\hline I don't want to be a target for discrimination of any kind & $5.88 \%$ & 1 \\
\hline
\end{tabular}

\section{Interview Results}

Perceived Barriers

After reviewing the results of the survey, 37 phone interviews were conducted with women academic librarians who indicated they would be willing to be interviewed. When asked about the barriers they experienced in getting or having a management position, all participants mentioned that they experienced barriers to getting a management position. The most frequently mentioned barrier was managing work responsibilities while caring for family and children. Twelve participants (both those in management and aspiring managers) shared that balancing work and family life was a challenge for them. Three participants felt they were responsible for a greater share of the caretaking and housekeeping than their partners, which made it harder for them to manage both work and home responsibilities. Others shared that their partner's job took priority over their own or that they had to leave jobs when their partners could not get positions, especially in academia. One person explained: "my husband is still looking for a position and I've been here almost a year. That's been really difficult." Others described leaving positions in librarianship, making lateral moves within institutions, or moving from management into nonmanagement to meet their partners' employment needs.

Managing caring for children while managing or pursuing management positions was also a common challenge. Eleven current managers said that having children while having their library jobs was difficult. One explained that she had less time available to devote to work projects outside her regular work hours, saying that "prior to having a little one, I was a workaholic... [now] I have a little person relying on me. I get charged by the minute if I am late at daycare picking her up." Three nonmanagers mentioned that caring for children kept them from focusing fully on their careers. One participant explained, "I would say that my rank and my 
salary don't reflect my experience. I think that that has more to do with the gender stuff and having kids and willingly taking a lot of short-term, part-time positions as part of that, whereas if we had free daycare for everyone I probably would've started working full-time a lot earlier than I did after having children." Some mentioned that they felt very guilty when they focused on work. One participant shared: "I think [women] have that guilt of not being at every single school event or how are we going to make this work." Three participants said they chose not to have children because they wanted to focus on work and thought it would be too hard to balance career and parenting.

Other participants, however, rejected the notion that family and work don't fit together. One explained that it was important for her to show other women interested in library management that they could succeed in the job and also succeed as parents, saying that "part of what I want, right, is to prove to myself and to the rest of the people who work in my institution, or who know me, that you can have ... the job and be a good mother. It is possible." She was motivated by being a working mother. Two participants mentioned that having children helped them improve their work-life balance because they had to set boundaries on the time and energy they devoted to work.

In addition to family concerns, several women mentioned barriers related to gender. Nine interviewees talked about experiencing or witnessing overt acts of sexism. For instance, one participant spoke of being harassed by a high-level donor to the institution and being told by her male colleagues that she should accept this treatment to avoid jeopardizing the donor relationship. One participant said that she "[hasn't] experienced real serious sexual harassment or anything like that at work" but then recounted being excluded from an informal bibliophilic society in town because she was a woman. Women mentioned being excluded from social events that their male bosses or colleagues planned and attended.

Several women recounted challenges that they did not identify as sexism but that they thought were related to gender. One woman participated in a planning meeting for a major facilities activity but "six months later I found out through the grapevine that nothing had been done the way that we were told it was going to be done, and that a decision was made by a department head in a different department to do it differently." Others mentioned actions where they felt like men in the room condescended to them. One participant mentioned, "I've been called girl, not in a malicious way, but in a 'Good job, girl,' pat on the head kind of thing." Others mentioned being told to smile more or be friendly, being interrupted in conversation, or having ideas that they shared rejected out of hand. However, in many cases, women were reluctant to label these events as sexism. One woman echoed a sentiment of many others, saying, "I try to give people the benefit of the doubt, right? In my head [I think], 'Well, I'm sure they didn't mean it."'

Fourteen participants talked about ways in which men were afforded privileges that made it easier for them to succeed in management positions. Some felt that men were given additional training or encouragement to take leadership roles. One participant noted that "men are perceived as leaders and groomed for leadership positions solely on the basis of their stereotypical masculine personality traits, whereas women have to fight against misperceptions of their stereotypically feminine personality traits in order to just achieve the same playing field." Other women mentioned more subtle examples, such as men being given the benefit of the doubt and allowed to retain their power and position despite failing to meet organizational objectives. Speaking of a former supervisor, one respondent said that "he was given way more benefit of the doubt than he would have been had he been a woman... [He] didn't get things done, wasn't able to delegate... it was just chaos." Participants described male colleagues who were disorganized, disinterested, 
or incompetent being allowed to persist or getting jobs for which they were unqualified. For example, speaking of a male and a female colleague applying for the same management position, one participant explained:

his presentation for his interview portion, it was just a joke. He didn't address the topic. He had pictures of his family. He talked about being in the military. He talked about playing sports. She very much addressed the issues. She talked about her past experiences. It was a night and day, but we all knew going into it that she didn't stand a chance because there are [people] ...being groomed by the administration. He was one of those.

In other examples, participants perceived that men received preferential treatment by the administration, such as getting more time to meet with associate deans, more funding for travel, and more opportunities to lead high-value projects.

Many participants noted the prevalence of gendered behavioral expectations that influenced their work lives. One of the most common examples was that women were expected to collaborate, but often at the expense of completing their own work. One person noted that she was asked to complete a project, but was told that while she learned how to do the project she was also expected to teach and train several other people on how to use the tools for the project at the same time. She explained that this expectation to collaborate made it much harder for her to get the project done and also prevented her from being recognized for getting the project finished: "instead of being a project that I implement, I now have to shepherd 20 people along with me through this process the first time, which makes it much more laborious, and also reduces... the amount of the credit that [I] get for it." A participant also stated: "I've had projects that I have led and brought people through that process only to find male librarians on the other end claiming credit for it, and being perceived as having that responsibility. So there's this you're supposed to bring people up from the baseline and then they get to say that they did this, and you're just left off to the side....There's no winning there. You either keep your mouth shut and ...let someone take credit for your work, or you fight against it and you become a shrew."

Other women also mentioned that any assertiveness tended to lead to a negative outcome for them, even when men who behaved the same way did not face negative consequences. One manager explained: "I've watched women who are just absolutely amazing who do fantastic things, who are just smart and engaged and they don't quite seem to get the same number of opportunities and/or if they rock the boat a little bit, they get labeled as either bossy, or over emotional, or a trouble maker." In one case, a woman described working with a colleague to develop a new workflow for a project based on her extensive expertise in the area, which generated some conflict with coworkers. She noted that she told male colleagues that "we would take their feedback and... make changes as we could, but we were not willing to undermine the integrity of the system by trying to make a different system for everybody so they could all have their own personal preferences." In the end, she and her colleague "were strongly penalized for that by multiple departments and people in the organization, including leadership." Another woman mentioned: "I was told I was being too assertive... I would have [my male colleague] bring things up that needed to be done because our dean at that time... would take it from him but not from me." When she suggested new ideas, another participant was warned by her associate dean to avoid being "uppity" by making too many suggestions. Participants also felt that they were expected to avoid negotiating or asking for what they wanted. One woman explained: "when I took on additional responsibilities I asked for 
a raise. The person [said] 'okay, but you're going to do these other responsibilities.' I said, 'Not unless I get a raise because it's a significant amount of work.' I think I was very calm and reasonable about it, and this person got very angry at me and told me I was being very aggressive."

Women mentioned cases where they were penalized for assertiveness but also penalized for being conflict avoidant. One woman explained her belief that "if you're well liked then it probably means you haven't made anyone unhappy and [that] you've been very conflict avoidant, and I don't know that that's necessarily a strong leadership skill that's rewarded. If you haven't been conflict avoidant and you stood up for yourself, then that's not necessarily seen in women to be a leadership skill. Whereas I feel like both are perceived as a leadership skill in men."

Another participant echoed this sentiment: "We're told to lean in, and to have a spot at the table, and make sure that you have a voice. Then sometimes when we do that, that can backfire and it can be looked at as threatening, or as trying to take too much power, or something like that. I found it really difficult to walk that line."

In addition to feeling pressured to avoid assertiveness, others mentioned that they felt undue pressure to nurture their colleagues and perform emotional labor, defined as "the effort, planning, and control needed to express organizationally desired emotion during interpersonal transactions." 24 One participant explained that: "in my previous position, I and other female colleagues were asked to essentially nurture a resistant male colleague through a basic job responsibility.... There's this perception that women are helpers, and nurturers, and we're just supposed to make everything better." Another woman mentioned how, during a holiday, "no one would shut up about the last library director and how she made them all individual [gifts]. It was their expectation of [how] women library directors should be... cuddly and warm and would come back to them every day and ask them how their days were going." Similarly, another woman said that she was often expected to do this work instead of the men in her unit: "I was responsible for caring for employees, as in like the get well cards, and the collecting donations to buy flowers for a sick employee, and things like that. That had been delegated from my supervisor who was male. There was not really an expectation from that ...he would be doing those kinds of things."

In addition to being expected to nurture others, respondents also reported pressure to perform other forms of emotional labor or self-policing based on their gender. Many women reported that they were stereotyped as being overemotional or warned to avoid emotions in the workplace. One woman explained that "I had somebody tell me very early in my career... 'you have to leave your personal self at the door... you've got to keep all that separated from your work life or you're not going to be taken as being credible as a woman in the workplace."' Other women felt that they were expected to be perfect and to never make mistakes. One suggested that "if you are a dude and you make a bad decision as a manager, people are like, 'Oh, that was a bad decision.' If you are a woman and you make a bad decision as a manager, people are like, 'Well, she is a bad manager.'" Others avoided sharing their personal lives for fear of being seen as weaker in some way. Instead, they adopted a work persona. One person explained: "I have to be careful to do that divide between who I am out of work and who I am in work, down to how I talk and how I write." Others talked about feeling like they had to do more than their male colleagues to earn respect: "You just do what you have to do. I think as women, we always do more than we have to do anyway."

Others mentioned that they faced gendered expectations about performing low-status tasks. They described being ordered to take notes, plan parties, and organize social events, even at the expense of getting their required job responsibilities completed. One woman expressed exasperation over being asked to do manual labor, explaining: "I set up the food and I wash the 
dishes when it's done. I put the dishes to dry. Then, I have to go back when the dishes are dry and put them away. I'm not working in a cafeteria. I'm supposed to be a librarian. Why am I washing dishes?"

Other stereotypes that women mentioned included gendered expectations about clothing. Several mentioned a version of being policed for their clothing. One participant explained, "I remember being pulled aside when I first started and told like, 'Hey, maybe you should dress up a little more at work.' Even though I was matching the level of dress of my male co-workers."

In some cases, women mentioned that these barriers discouraged them from even trying to move into management positions. One woman who was a manager in the past said that she had one day hoped to go back to managing but that "the politics involved in that [and other challenges like] gender roles and other family pressure... I just don't know that I have the flexibility or even the stamina to go down that road." Another said that women "are too apt to say we're just going to be all things to all people all the time and suffer from burnout, and career dissatisfaction, and frankly just a lot of anger and disappointment."

In addition to gendered behavioral expectations and other challenges, a few participants mentioned a lack of self-confidence as a barrier. Seven participants indicated that they had to learn and practice self-confidence, while three mentioned that they think women need to support each other in developing self-confidence so that they can succeed. Many people echoed one participant's sentiment when she said she had to remind herself that "I did get hired into this position. I am the equal of these other people." Another mentioned that she felt a lot of anxiety and "worried that my approach to management might not fit with what people I managed were expecting." Others noted that lack of self-confidence is common; one explained that "I think it is almost implicit, especially I think sometimes in our culture with women. We are trained to think that somehow we don't deserve the opportunities we've gotten or we won't make it. I've never gotten over the sense that I'm on a constant job interview." Other women in turn felt that, despite their best efforts, they weren't confident that they were doing enough in their current positions: "I've been told that I'm taking too much on myself but that's just kind of how I do things... I struggle with that." Others felt anxious to even apply for management positions, afraid their qualifications were not good enough: "When I feel like I see a job that I feel totally qualified for, then I'll start applying to different position." A current manager noted a similar pattern in that "women are much less likely than men to take a leap forward into a job that they have less experience in. Women are much more likely to feel like they have to have strong experience in order to even try. I very strongly see that pattern in the people who report to me."

In addition to challenges based on self-confidence, several participants shared that relationships with coworkers presented barriers to getting or engaging in management roles. Some indicated that when they moved up into management roles, they experienced conflict with employees who were once their coworkers, and sometimes had difficulty obtaining respect and cooperation. For example, one participant shared that, once she became a manager, she experienced frequent conflict with employees who were older than she and who were now required to report to her. Participants who became managers sometimes lost friendships with coworkers. One participant shared that, after she was hired for a management position, a friend who had applied for the same position refused to speak to her. Participants who chose not to enter management sometimes discussed relationships as a factor that prevented them from applying for management positions. One shared that her colleagues got angry when she offered feedback or suggestions, which made her doubt they would accept her in a management role.

In addition to relationship challenges, participants also mentioned that they experienced discrimination that complicated their experiences in the workplace. Eight current managers, 
two nonmanagers, and one past manager shared that age discrimination was a factor that made it difficult for them to engage in management roles. Some believed that, because they were younger than other employees, they were treated as less competent or authoritative. Participants felt that others talked down to them or ignored them because of their age. For example, a participant reported that other coworkers addressed her by a diminutive nickname and explained that "there's a condescension because I look younger than I am and because I'm female and people don't think that I deserve respect even though I work really hard for that." Another mentioned that colleagues doubted her ability to be assertive on campus, questioning whether she would "appear authoritative enough or even aggressive enough to be able to challenge other people on campus in order to make those changes." Others perceived that their age played a role in people they supervised disliking them. One noted that she had to overcome many negative perceptions from people she supervised, noting, "I think that their fear of change and their fear of losing their position makes them very resentful of me and my age and my gender."

In addition to age discrimination, participants also faced other types of discrimination. Two people described instances where they were told they would never understand the significance of the school's culture or its celebrations because they were not a member of the dominant religion. One person described racial discrimination, such as being asked to be on every diversity committee because of their race, or fearing that they would not have full consideration when they applied for management positions. One person mentioned facing body size and weight discrimination as well.

\section{Reasons for Success}

In addition to reflecting on challenges they faced, women academic library managers were also asked to expand on their survey responses by saying more about what traits they felt made them successful. Six mentioned emotional intelligence as a major factor in their success, while another four said that being collaborative had helped them succeed. Other traits they mentioned as vital for success included a focus on harmony and equality, an ability to stay calm, an ability to be organized and focused, and a service orientation.

Another key area managers often mentioned as a trait or skill they developed over time was self-confidence in their abilities. Many mentioned that, although they had not felt ready when they began management, gradual success over time helped them become more selfconfident. Others said they realized they could make mistakes without causing catastrophic consequences, giving them faith in their own resilience. Others took heart from employees or members of administration who reassured them they were doing well or expressed confidence in their performance.

Others mentioned specific skills that made them successful or skills they had to learn to be successful, primarily effective communication and the ability to manage conflict or be assertive on behalf of themselves or their teams. Related skills included the ability to manage stress and do self-care effectively and to empathize with employees and in turn help them manage their stress and self-care. Those above the level of department head also frequently mentioned specific job-related skills, including facilities management, budgeting, and working with donors or stakeholders as areas where they had to learn new skills to be successful.

\section{Strategies for Overcoming Gendered Expectations}

A number of women also mentioned strategies they use to cope with the challenges of gen- 
dered expectations of their positions. For instance, they mentioned strategies they used to avoid seeming too aggressive in meetings, such as approaching others individually with their ideas and then sharing their ideas in larger forums once they knew they had support.

Others mentioned refining their strategies for communication. One participant mentioned that she has spent a lot of time "learning to communicate in a way that makes it clear when I am serious... to communicate effectively through that divide of socially 'acceptable' gender norm[s]." Another mentioned that she had to "retrain [herself] to be the one who smiles more while you're talking. I have certain coping mechanisms. I always bring my coffee with me to meetings and I just drink from my travel mug instead of speaking first." Another said, "If I go to a meeting of other directors or other supervisors I always have to say something in that meeting... That's my job, is to do that, and I can't sit back in the same way that maybe I would have in the past."

Others shaped their communication to better fit stereotypes about women to avoid the perception that they were being assertive or bossy. One person mentioned that she would "bargain in ways that don't seem like bargaining so that I can play into their expectations and still get what I want" such as telling vendors something like, "If you just gave us the same price as last year, maybe I could sell that to my boss. I don't know," instead of asking directly for a lower price. Another who wanted a reclassification said:

I went to my boss with a generic position from the University level of what somebody in the title of Library Supervisor would be doing. I gave that to her and she goes "Oh, this is really great. Is this your new position?" I said "no, but it should be though"... They actually agreed and I got that promotion to the title of Library Supervisor.

Thus, she found a way to ask for what she wanted while avoiding aggressive or overly assertive behavior.

Others used strategies around boundary setting to manage the challenges they faced. One manager explained that

Maybe the first couple of weeks that I was a manager, somebody was feeling like there was a crisis, and really wanted me to stay late at work to help him talk about it, but I needed to go because [of] my son, who was a baby at the time. I was like, "I'm sorry, but I've got to go." The person who wanted me to stay was just floored that I would leave. I was like, "I know. I get that this is important... we are going to talk about this tomorrow morning. It can wait until then. Right now, I'm going to go pick up my son."

Others mentioned explicit self-promotion as a strategy to get more opportunities and highlight their skills. One mentioned that she tried to "send out lots of announcements about what we were doing and awards we've won and mentions and praise and feedback from users and I just had to start basically doing my own PR campaign for myself."

\section{Respondents' Strategies for Professional Development}

In addition to reflecting on skills they had to learn to be successful, women in management positions were also asked to reflect on the professional development activities they undertook. Nonmanagers were asked what they were doing to prepare for career growth. Nonmanagers 
often mentioned doing committee work to build leadership skills. Although many had positive experiences, others felt their experiences working on committees were lacking. One participant noted that "unimportant committees are the ones that are given to women.... The ones that are perceived as having weight are almost exclusively led by men and/or folks with tenure." Thus, women felt that they missed out on opportunities to lead high-value projects. One stated, "I might have some leadership skills, but I also feel like I've not had enough opportunities to really demonstrate those skills." At the same time, however, women who were already managers reflected often on opportunities where someone, usually a superior, gave them a chance to lead a high-value project. Others mentioned having opportunities such as chairing the Faculty Senate or taking on high-value committee work in regional committees, suggesting that not all participants felt they lacked opportunities to gain leadership skills through committee work. Women in management also mentioned the value of committee work, although less frequently.

Both women managers and women interested in management mentioned the value of mentoring. Eleven women in management mentioned explicit encouragement from their supervisors, such as opportunities to attend professional meetings in their areas of interest. Others mentioned bosses who explicitly trained them for management roles and gave them opportunities to practice management skills. Women interested in management also occasionally reported similar opportunities. One early-career librarian noted, "[my] director is more willing to give me more projects because he knows that I want to be a director in the future and that that will help me get there." Others mentioned that past supervisors have helped them in situations where they felt uncertain, providing both advice and emotional support.

In addition, many women in management mentioned the value of peer mentoring and said they relied on colleagues whom they spoke with face to face but also via listservs and other online tools to give feedback on tricky situations and provide emotional support. Three women mentioned that their spouses, who were professors or managers in other fields, provided a lot of support.

Formal leadership institutes were another way that women in management gained confidence and skills. Several attended national programs like the ACRL Harvard Leadership Institute and the UCLA Senior Fellows Program and described these programs as good opportunities to develop relationships with peers, although attendance at these programs was much more common among deans and associate deans. Other women managers mentioned attending campus-level or state-level leadership programs as well. Some women interested in management also mentioned doing programs like the ALA Emerging Leaders program as an important opportunity. Notably, many women mentioned the benefits of meeting peers and forming relationships as equally or more important than the curriculum at these events. The most common professional development strategy for women managers, however, was informal or self-led training through activities like reading about management.

Others benefited from meeting informal mentors at various levels of the organization, often through happenstance. One woman manager explained that "finding that kindred spirit that you can hang with and really talk things through" was invaluable to success. When asked about formal mentoring, a few women mentioned participating in formalized programs through their organizations or though organizations such as the Association for College and Research Libraries (ACRL) or the Library Leadership and Management Association (LLAMA) (now part of CORE). However, several people also mentioned these mentoring opportunities were unhelpful for a variety of reasons, such as lack of a personal relationship or infrequent 
communication. Instead, women interested in management seemed to focus most of their professional development efforts on committee work and taking on projects that taught them new skills at work and much less on networking. These findings suggest that women use a variety of strategies to build management and leadership skills, including both formal and informal mentoring.

\section{Respondents' Recommendations}

When discussing their successes and challenges, many women in management also had ideas about what would make pursuing and achieving management positions easier for women in libraries. For instance, many of them talked about the ingrained influence of sexism and implicit bias in the profession and the need for the profession to educate itself about the dangers of subtle prejudices. Many participants speculated that some of the sexism they felt was unintentional, a byproduct of working in a gendered society. One person explained, "we've had male employees who have been able to work their way up internally from student employee to management and department head positions. We have no female employees who have done that, even though our administration is primarily female." Several women echoed similar statements, calling for increased education about the role of sexism in hiring and management and for new strategies to mitigate the effects of these biases.

Many current managers talked about the need for women to learn assertiveness and self-confidence and to practice asking for what they want, both because the women deserve their compensation and because women who do not ask are at a disadvantage since their male coworkers are often willing to ask for management positions, pay increases, or other job perks. As one current manager explained: "I have mostly women [who] report to me, but a few men, and I would say by and large men tend to ... almost overestimate their leadership skills. They really very quickly want to advance into leadership positions. Women tend to underestimate their skills where they could lead and they're very skilled, but they have to be encouraged to do that. Men do that every six months. 'I just did this thing. Give me a new title.' A woman's like, 'I did this thing because I assumed that's what the thing is you wanted me to do. That's okay. I don't need any acknowledgement."'

Some suggested that this lack of assertiveness sometimes manifested in timidity or in an unwillingness to take risks. One manager noted that "most men are not afraid to just go do something, and they're not worried about if they're going to fail at it or do terrible. I feel like women are less likely to just jump in and take a chance." One manager also mentioned that she thought most women were too committed to their jobs and took conflicts far too personally, suggesting that women should practice stepping back from the job and finding other ways to derive their self-worth.

Women managers also suggested that women needed more coaching and support, both in terms of being encouraged to apply for management positions and in terms of training to succeed in management. This support may help more women begin to think of themselves as leaders and actively pursue management positions. As one manager explained: "I've managed a lot of people at this point. The men are always coming to me and saying, 'I would be a good manager. I think you should make me a manager. I'm super-awesome at what I do and that's what I think you should do for me.' The women, if I asked them to be managers will say, 'Oh, do you think I would be

good at it?' Or, if they ask me to be manager, they don't say, 'I'm super-awesome, you should make the manager.' They say, 'I think I would do a better job than that guy.'" 
Many women managers also recounted cases where they were explicitly encouraged to consider management by a director or supervisor. Others mentioned that seeing other women in similar positions made them more confident, suggesting that having women coach other women in how to get and keep management opportunities is important. One current dean said: "I look around the table now at meetings that I' $m$ in with other deans and directors and there are a lot more women at the table [than] there used to be. I think that when you see yourself at the table and see others like you at the table it's very motivating and encouraging."

Another related recommendation was that women do more to support each other in the workplace. One manager explained, "In a situation as recently as this week, I felt like what was happening was white guys were looking out for white guys in my workplace, and women often don't do that for one another. I tried to stand up a little bit and be like, 'Well, also, her. Maybe you didn't notice her. Maybe you didn't know about this background'... Part of what I can do is open doors and create opportunities for other women because I'm used to saying what I want."

Another female manager suggested that women in management should work harder to model work-life balance and to show that succeeding in management and maintaining a healthy life is possible. She suggested that "women look at other women in leadership positions and they don't see anybody whose life they want. That is partly what keeps them from pursuing it.... When I looked at other managers, I didn't see anybody whose life I wanted. What I saw was people who were really out-of-balance, who worked all the time, who didn't have families."

These recommendations highlight the need for administrators to support women interested in management through coaching and professional development, and to help minimize the impact of sexism and implicit bias in hiring decisions.

\section{Reported Reasons to Avoid Management}

When women indicated in the survey that they were unsure about managing or disinterested in management, the interviews provided an opportunity to learn more about their reasons for being uncertain or lacking interest. The major reasons respondents reported were similar to responses in the survey. Several preferred working on projects rather than managing people, while others did not want to or were unsure if they felt comfortable handling the conflict that might arise when managing employees. Others mentioned other interests outside of work, especially caring for families, that made them less interested in the added burden or potential stress of management responsibilities.

Women who managed in the past but were not currently managers also faced barriers staying in management positions. Three participants mentioned that lack of support within their institutions discouraged them from seeking management positions, made obtaining these positions difficult, or inhibited them in performing positions successfully. Sometimes participants believed that this lack of support was motivated by sexism, but at other times they described it as simply endemic to their institution; these factors emerged as independent barriers, whether motivated by sexism or not. Lack of training was an oft-cited problem in this category; participants felt that they were not adequately prepared by their organization to take on leadership roles. One person who managed previously but not at the time of the interview said, "I did not necessarily feel like [administration] wanted me to succeed as a manager as much as they didn't want me to fail."

In addition to lack of support, some participants mentioned lack of compensation as a challenge. One person who had been a manager in the past gave up her management duties 
because of lack of compensation, noting, "salary doesn't buy happiness, but salary buys necessities. I think we fund what we value as institutions." Not only women who quit managing, but also current managers, described lack of compensation as an ongoing problem; many were frequently told that they would have to take on additional responsibilities to meet organizational needs without a corresponding pay increase. One person explained that, after an associate dean left her institution, she "was told that I would take on his responsibilities with no corresponding increase in pay." These challenges discouraged women from taking on management roles.

Women managers also faced other challenges; all of the managers said that they felt quite busy a lot of the time, although none said that they felt totally overwhelmed and incapable of doing the job. Others mentioned that some parts of the job, such as negotiating conflicts with employees, were especially unpleasant. Others mentioned that external factors, such as state regulations and budget cuts, made life hard because they felt they had a lot to accomplish with too few employees and resources. The most common complaints women in management mentioned were dealing with bureaucracy, such as having to fill out a lot of paperwork to hire people, having to schedule people, and having to conduct disciplinary reviews or performance evaluations. Eight women who were associate deans also said explicitly that they did not want to be deans because deans have much more responsibility for connecting with outside stakeholders and legislators. In short, schmoozing and paperwork seemed to be the hardest parts of the job.

Several interview participants also commented on why they like the job. Five managers or past managers mentioned that they saw themselves as coaches, supporting their employees' growth. Five also described themselves as advocates for employees and mentioned taking pleasure in tasks like helping their employees find the resources they needed to do their jobs better. One participant said, "I want to be able to help put structures into place that can help [my employees] be successful and accomplish the awesome things I know that we're all capable of." Others felt happy when they saw their employees grow in their careers over time. One person mentioned that "giving people opportunity when I can help people grow and develop under my leadership I think is a very rewarding thing." Others liked connecting units across campus and advocating for the library's work: "I like fitting in the spaces where I'm helping things happen across campus and connecting people to other people." Thus, women managers seemed to enjoy helping their employees thrive at work and building excellent programs and services.

\section{Discussion}

This research examined whether women academic librarians felt they faced barriers in pursuing and achieving management positions, what barriers they faced, what factors they considered important for their success, and how the experiences of those who were in management positions differed from those who were not. Although many women mentioned facing barriers in management, some did not; there was no single factor that differentiated women who felt no barriers from those who did. It may be that women who did not experience barriers had different combinations of life and career circumstances that influenced their experiences compared to women who did experience barriers.

The most common barriers women described in the survey were learning new skills to be a manager, balancing work and family life, learning to think of themselves as managers, and navigating political difficulties. These findings were consistent with interview findings as well. Many of the skills women had to learn, such as communicating appropriately or 
negotiating in ways that match gender norms, are attached to gendered behavioral expectations. This is consistent with Olin and Millet's findings that gendered behavioral expectations shape women's experiences in library management. ${ }^{25}$ However, it is also a testimony to the fact that women find ways to overcome and adapt to these challenges to meet their goals successfully. These findings suggest the need for further exploration into how gendered behavioral expectations shape women academic librarians' experiences to make sure that these women are comfortable and able to achieve as much as they can in the workplace.

Although many women described examples of gendered expectations, many women did not characterize their experiences as sexism or sexual discrimination. However, even women who did not characterize their experiences as sexual harassment shared numerous examples of instances where they felt sexism might have played a role in their experiences. This is consistent with the findings of a recent study that administered the Sexual Experience Questionnaire to academic librarians. They noted that:

$78 \%$ of the sample indicates experience with gender harassment and $64 \%$ indicate an experience with seductive behavior, but only $21 \%$ of the sample indicate experience with sexual harassment more generally. The discrepancy between the specific dimensions of sexual harassment and the global measure may suggest that individuals who experience gender harassment or seductive behavior do not necessarily characterize these experiences as sexual harassment. ${ }^{26}$

Based on a literature review of sexual harassment experiences in other professions, such as nursing, scholars found that "thinking about sexual harassment as 'part of the job' seems to be common in other female dominated professions." ${ }^{27}$ This finding is consistent with Britton's assertion that "women workers tend not to see gender inequality as due to an oppressively chilly climate." ${ }^{28}$ Hart notes that "lay understandings of sexual harassment are narrow, so people may not label sexual harassment experiences as such." ${ }^{29}$ In addition, women may ignore or minimize gender inequality or sexual harassment. ${ }^{30}$ The extent to which women did not label these experiences as sexism suggests that part of the challenge of having more women in management might be labeling and identifying instances of discrimination and developing strategies to combat them effectively. Given the larger cultural narrative arising right now around gender and sex discrimination, such as the \#metoo movement, libraries have an important opportunity to consider how gender affects the workplace and to take action to ameliorate sex-based discrimination and harassment.

Even in cases where sexism was not mentioned, most women did report structures in the workplace that seemed to favor men. Women reported instances of being required to collaborate or work in ways that effaced their own contributions to the organization, which in turn prevented them from having a strong record of individual project success to move up in the organizations. When women did try to speak up or demand more opportunities, in some cases they were chastised for being aggressive in ways that the men they worked with were not. This finding is consistent with research showing that women may be penalized for showing assertiveness, which is perceived as inconsistent with gender norms for women's behavior. As Eagly and Karli (2012) explained, "verbally intimidating others can undermine a woman's influence, and assertive behavior can reduce her chances of getting a job or advancing in her career. Simply disagreeing can sometimes get women into trouble." ${ }^{31}$ This finding 
suggests that gendered communication expectations may still play a role in women academic librarians' experiences. Respondents' reports that they were asked to nurture colleagues and participate in low-status labor are also consistent with Eagly and Karli's (2012) findings that women are often expected to be communal and nurturing, rather than active. ${ }^{32}$ Both women and men may need support. For instance, people of any sex and gender can be encouraged to participate in the nurturing of colleagues or in doing housekeeping tasks.

In addition to gender, several participants mentioned age discrimination as a major challenge. Although no one mentioned age discrimination as an older person in this sample, this does not mean that these issues do not happen. One important caveat to generalizing about age, however, is raised by Gardner and Galoozis, who found that a "problem in generational research in LIS is a focus on a singular marker of identity (age or generational cohort) while race, sexual orientation, gender expression, ethnicity, and other markers are conspicuously absent. ${ }^{33 \prime \prime}$ This suggests that experiences with age discrimination are connected to and intersect with other identity markers. Although sex was salient in this study, more research should be done about how women's experiences in academic libraries are shaped by their other identities.

Women managers and women interested in management also described political difficulties as a major challenge, a phrase that seems to encompass a variety of problems, including lack of support by administration, challenges negotiating relationships with would-be subordinates or colleagues, and lack of opportunity to move formally into positions where they occupied interim roles. Women who left management or did not want to manage also suggested that politics, especially conflicts with employees or administrators, discouraged them from pursuing management. This finding suggests that women would benefit from more support in managing relationships in the workplace, which research has shown may be a cause of occupational stress. ${ }^{34}$ More research examining specifically how academic library managers understand political difficulties and how they manage those difficulties would also provide more insight into how to manage political difficulties successfully. In addition, since many women mentioned informal support networks and mentoring as important in their professional development, continuing to find ways to encourage the development of these social networks may be one way to help women manage such difficulties.

Work-life balance and the need to balance family obligations presented a common barrier for both women managers and women interested in management. These women noted that they did a disproportionate amount of emotional labor for their colleagues. Although some women saw their emotional intelligence as a strength, other women felt burdened by the need to perform this emotional labor. These findings were consistent with Manchester, Leslie, and Dahm's review of the literature on how family responsibilities affect career progressions; they found that "laboratory-and field-based experiments, in which all differences between mothers and childless women are accounted for, document a motherhood penalty. Mothers are less likely to be hired, called back for an interview, given training, and promoted." ${ }^{35}$ In spite of being a female-dominated profession, mothers still face significant challenges in managing their responsibilities in librarianship. This suggests that there is an important opportunity to consider how to best support mothers and indeed all parents as they pursue positions as academic librarians.

Interestingly, very few women mentioned low self-esteem as a major reason that they felt they faced barriers in management. Several women interested in management did say that they did not feel ready to take on management roles, which could be evidence that women underes- 
timate their leadership potential. More than half $(57 \%)$ of women managers also mentioned that learning to think of themselves as managers was a barrier, suggesting that lack of self-esteem was a challenge. Future research that asked both men and women librarians to rate their leadership potential while controlling for differences in experience or demographics would be useful to learn more about whether women librarians do rate their leadership potential lower than men.

Women managers' self-reported reasons for their success also indicated that many attributed their success to personal qualities and characteristics. Although many mentioned specific skills they had to learn, such as operations management or conflict management, they also reported personality traits that helped them succeed, many of which clustered around emotional intelligence and building strong relationships with their colleagues. This suggests that women interested in management should spend time cultivating their communication and conflict resolution skills as much as they focus on learning hard skills. In addition, the recommendations that libraries work to overcome gendered behavioral expectations, provide coaching and support to women in management, and encourage women to support other women suggest that women managers succeed when they feel supported in considering and pursuing management and when they are able to build supportive relationships. More research into what factors make women librarians feel supported in considering library management would elucidate how libraries could better support the development of women managers.

In exploring how women interested in management perceived factors for success and barriers compared to women in management, the differences were less noticeable than expected. Perhaps the most common was that women interested in management tended to think in terms of getting a necessary skill set, applying for jobs with gradually increasing responsibility, and then eventually reaching a management zenith. Although some women followed this path, many women managers got their positions as others in their organizations left their positions or as they faced reorganizations.

\section{Limitations}

This study has several limitations. The sample size for both the survey and interviews was small, meaning that the results of this research are not statistically generalizable to women librarians as a whole. This methodology and sample were not designed to measure the prevalence or salience of the themes uncovered in this research, although information about the number of participants who reported specific kinds of themes was included for context.

In addition, this research predominantly included White or Caucasian participants. However, numerous research studies show that women of color in librarianship face additional challenges, ${ }^{36}$ such as regular experiences of microaggressions. ${ }^{37}$ As Thomas, Trucks, and Kouns noted, "Members of marginalized groups, especially people of color and those who identify as LGBTQIA, experience hidden workloads, microaggressions, early burnout and lower retention. ${ }^{\prime 38}$ Further research should be done, as Swanson, Tanaka, and GonzalesSmith suggested, on how librarians' intersecting identities inform their lived experiences. ${ }^{39}$

Since participants self-selected, it is also possible that this study overreported the experiences of women who were interested in management issues. In addition, survey research is a challenge because respondents may not self-report accurately; the same is also true in interviews. ${ }^{40}$ More research is needed on women in library management, specifically their experiences pursuing management or their reasons for avoiding management. 


\section{Conclusion}

This study addressed a gap in library literature by exploring how women academic librarians understood and described their career progressions. By learning more about the barriers that women academic librarians face in management positions or in aspiring to management, as well as the factors for success that help women academic library managers succeed, we may be able to design interventions that help women gain management experience or overcome barriers to taking on management if they want to do so. This study may also help women academic librarians understand barriers that may discourage their advancing to management positions and help managers, human resources personnel, and deans develop interventions to encourage women's persistence in management positions. Although our profession has certainly made great strides in encouraging women in management, there is still an opportunity for us to learn more about how gender and/or sex influence the work life of academic librarians. This research also provided more information about how women experience and understand their own work in libraries and how gender and/or sex may play a role in those experiences; such research is an opportunity to explore how our profession can limit the negative outcomes of gendered behavioral expectations and create an environment for "leaders, male or female or people who don't identify in those ways, to be valued for what they each bring to their organizations." ${ }^{41}$

\section{Acknowledgments}

The author would like to acknowledge the University of Utah's Office of the Vice President for Research (VPR) for providing funding to support this project. Many thanks as well to all of the folks that participated in this research and reviewed it, including the editor and anonymous reviewers. Special thanks to Sarah LeMire, Erika Church, Devan Church, and Sarah Bryan for their detailed feedback. 


\section{Appendix. Women's Academic Librarians' Career Progression}

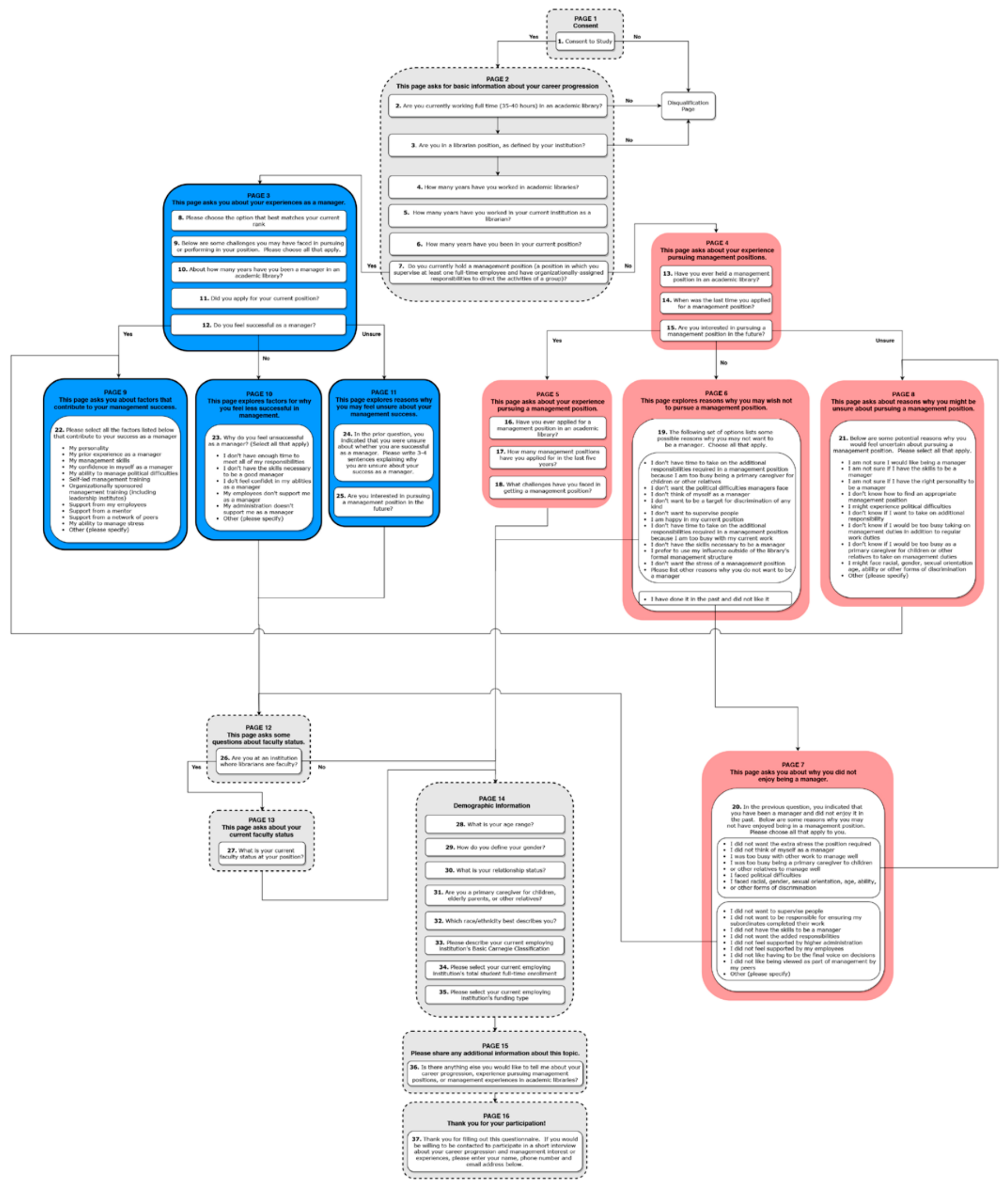




\section{Notes}

1. Jason Martin, "Transformational and Transactional Leadership: An Exploration of Gender, Experience, and Institution Type," portal: Libraries and the Academy 15, no. 2 (2015).

2. Kathleen DeLong, "Career Advancement and Writing about Women Librarians: A Literature Review," Evidence Based Library and Information Practice 8, no. 1 (2013): 59-75; Jessica Olin and Michelle Millet, "Gendered Expectations for Leadership in Libraries," In the Library with the Lead Pipe (2015), www.inthelibrarywiththeleadpipe.org/2015/libleadgender/.

3. Camille Thomas, Elia Trucks, and H.B. Kouns, "Preparing Early-Career Librarians for Leadership and Management: A Feminist Critique," In the Library with the Lead Pipe (2019), http://inthelibrarywiththeleadpipe. org/2019/early-career-leadership-and-management/:

4. Alice Hendrickson Eagly and Linda Lorene Carli, Through the Labyrinth: The Truth about How Women Become Leaders (Boston, MA: Harvard Business Press, 2007).

5. Joan Acker, "Hierarchies, Jobs, Bodies: A Theory of Gendered Organizations," Gender \& Society 4, no. 2 (1990); Dana M. Britton and Laura Logan, "Gendered Organizations: Progress and Prospects," Sociology Compass 2, no. 1 (2008); Christine L. Williams, Chandra Muller, and Kristine Kilanski, "Gendered Organizations in the New Economy," Gender \& Society 26, no. 4 (2012).

6. Robert Swisher, Rosemary Ruhig DuMont, and Calvin J. Boyer, "The Motivation to Manage: A Study of Academic Librarians and Library Science Students," Library Trends 34 (1985).

7. Acker, "Hierarchies, Jobs, Bodies"; Williams, Muller, and Kilanski, "Gendered Organizations in the New Economy"; Eagly and Carli, Through the Labyrinth, 2007.

8. Sheryl Sandberg, Lean In: Women, Work, and the Will to Lead (New York, NY: Alfred A. Knopf, 2013).

9. Gerry Pallier, "Gender Differences in the Self-Assessment of Accuracy on Cognitive Tasks," Sex Roles 48, no. 5/6 (2003).

10. Linda Babcock and Sara Laschever, Women Don't Ask: Negotiation and The Gender Divide (Princeton, NJ: Princeton University Press, 2003); Lisa A. Barron, "Ask and You Shall Receive? Gender Differences in Negotiators' Beliefs about Requests for a Higher Salary," Human Relations 56, no. 6 (2003); Deborah M. Kolb, “Too Bad for the Women or Does It Have to Be? Gender and Negotiation Research over the Past Twenty-Five Years," Negotiation Journal 25, no. 4 (2009).

11. Christine L. Williams, "The Glass Escalator: Hidden Advantages for Men in the 'Female' Professions," Social Problems 39, no. 3 (1992): 253-67; Adia Harvey Wingfield and Ranell L. Myles, "Still a Man's World? Revisiting Men Who Do Women's Work," Sociology Compass 8, no. 10 (2014); Christine L. Williams. "The Glass Escalator, Revisited: Gender Inequality in Neoliberal Times, SWS Feminist Lecturer," Gender \& Society 27, no. 5 (2013): 609-29.

12. Kathleen De Long, "True North Journeys in Leadership of Women Library Directors in Canadian Academic Libraries," diss., (Simmons College, 2012); Sharon K. Epps, "African American Women Leaders in Academic Research Libraries," portal: Libraries and the Academy 8, no. 3 (2008).

13. Marta Mestrovic Deyrup, "Is the Revolution Over? Gender, Economic, and Professional Parity in Academic Library Leadership Positions," College \& Research Libraries 65, no. 3 (2004); Barbara B. Moran, Elisabeth Leonard, and Jessica Zellers, "Women Administrators in Academic Libraries: Three Decades of Change," Library Trends 58 , no. 2 (2009).

14. Virginia E. Schein, "The Relationship between Sex Role Stereotypes and Requisite Management Characteristics," Journal of Applied Psychology 57, no. 2 (1973).

15. Anne M. Koenig et al., "Are Leader Stereotypes Masculine? A Meta-analysis of Three Research Paradigms," Psychological Bulletin 137, no. 4 (2011).

16. Kenneth S. Rhee and Tracey H. Sigler, "Untangling the Relationship between Gender and Leadership," Gender in Management 30, no. 2 (2015); Renee Warning and F. Robert Buchanan, "An Exploration of Unspoken Bias: Women Who Work for Women," Gender in Management 24, no. 2 (2009); Kim M. Elsesser and Janet Lever, "Does Gender Bias against Female Leaders Persist? Quantitative and Qualitative Data from a Large-Scale Survey," Human Relations 64, no. 12 (2011).

17. Rhee and Sigler, "Untangling the Relationship between Gender and Leadership"; Alice H. Eagly and Steven J. Karau, "Role Congruity Theory of Prejudice toward Female Leaders," Psychological Review 109, no. 3 (2002).

18. Laurie A. Rudman, "Self-promotion as a Risk Factor for Women: The Costs and Benefits of Counterstereotypical Impression Management," Journal of Personality and Social Psychology 74, no. 3 (1998): 629-45; M.E. Heilman, "Gender Stereotypes and Workplace Bias," Research in Organizational Behavior 32 (2012): 113-35. 
19. Janine Bosak and Sabine Sczesny, "Am I the Right Candidate? Self-Ascribed Fit of Women and Men to a Leadership Position," Sex Roles 58, no. 9/10 (2008).

20. Mary Hogue and Robert G. Lord, "A Multilevel, Complexity Theory Approach to Understanding Gender Bias in Leadership," Leadership Quarterly 18, no. 4 (2007).

21. Robin J. Ely and Deborah L. Rhode, "Women and Leadership: Defining the Challenges," in Handbook of Leadership Theory and Practice, eds. Nitin Nohria and Rakesh Khurana (Boston, MA: Harvard Business Publishing, 2010).

22. Laurie A. Rudman and Julie E. Phelan, “The Effect of Priming Gender Roles on Women's Implicit Gender Beliefs and Career Aspirations," Social Psychology 41, no. 3 (2010).

23. John W. Creswell, Research Design: Qualitative, Quantitative, and Mixed Methods Approaches (Thousand Oaks, CA: Sage, 2013), 15-16.

24. J. Andrew Morris and Daniel C. Feldman, “The Dimensions, Antecedents, and Consequences of Emotional Labor," Academy of Management Review 21, no. 4 (1996): 987.

25. Olin and Millet, "Gendered Expectations for Leadership in Libraries."

26. Candice Benjes-Small et al., "Quantifying the \#metoo Narrative: Sexual Harassment in Academic Libraries," in Recasting the Narrative: The Proceedings of the ACRL 2019 Conference (Cleveland, OH, April 10-13, 2019), 66.

27. Benjes-Small, et al., "Quantifying the \#metoo Narrative," 70.

28. Dana M. Britton, "Beyond the Chilly Climate: The Salience of Gender in Women's Academic Careers," Gender \& Society 13, no. 1 (2017): 23.

29. Chloe Grace Hart, "The Penalties for Self-Reporting Sexual Harassment," Gender and Society 33, no. 4 (2019): 536.

30. Heather McLaughlin, Christopher Uggen, and Amy Blackstone, "The Economic and Career Effects of Sexual Harassment on Working Women," Gender and Society 31, no. 3 (2017): 333-58.

31. Alice H. Eagly and Linda L. Karli, "Women and the Labyrinth of Leadership" in Contemporary Issues in Leadership, eds. William E. Rosenbach, Robert L. Taylor, and Mark A. Youndt (New York, NY: Routledge, 2012), 152.

32. Eagly and Linda L. Carli, "Women and the Labyrinth of Leadership," 152.

33. Carolyn Caffrey Gardner and Elizabeth Galoozis. "False narratives of generational difference in academic libraries: Toward an intersectional approach." The Library Quarterly 88, no. 2 (2018): 185.

34. Akanji Babatunde, "Occupational Stress: A Review on Conceptualisations, Causes, and Cure," Economic Insights - Trends and Challenges 2, no. 3 (2013): 73-80.

35. Colleen Flaherty Manchester, Lisa M. Leslie, and Patricia C. Dahm, "Family Responsibilities and Career Outcomes: Discriminatory and Nondiscriminatory Explanations," in The Oxford Handbook of Workplace Discrimination, eds. Adrienne J. Colella and Eden B. King (Oxford, UK: Oxford University Press, 2015), 204.

36. Juleah Swanson, Azusa Tanaka, and Isabel Gonzalez-Smith, "Lived Experience of Academic Librarians of Color," College \& Research Libraries 79, no. 7 (2018): 876-94; Kimberley Bugg, "The Perceptions of People of Color in Academic Libraries Concerning the Relationship between Retention and Advancement as Middle Managers," Journal of Library Administration 56, no. 4 (2016): 428-43, https://doi.org/10.1080/01930826.2015.1105076.

37. Jaena Alabi, "Racial Microaggressions in Academic Libraries: Results of a Survey of Minority and Non-Minority Librarians," Journal of Academic Librarianship 41, no. 1 (2015): 47-53, https://doi.org/10.1016/j.acalib.2014.10.008; Jaena Alabi, “'This Actually Happened': An Analysis of Librarians' Responses to a Survey about Racial Microaggressions," Journal of Library Administration 55, no. 3 (2015): 179-91, https://doi.org/10.1080/019308 26.2015.1034040. 53.

38. Thomas, Trucks, and Kouns, "Preparing Early-Career Librarians for Leadership and Management," para

39. Swanson, Tanaka, and Gonzalez-Smith, "Lived Experience of Academic Librarians of Color."

40. Debra J. Rog and Leonard Bickman, The SAGE Handbook of Applied Social Research Methods, 2nd ed. (Los Angeles, CA: SAGE Publications, Inc, 2009), 20.

41. Olin and Millet, "Gendered Expectations for Leadership in Libraries," para 2. 